\title{
Investigation of Spodumene-bearing Rock as a Flux for Bone China Production
}

\author{
L. A. Carus, S. R. Bragança*
}

\author{
Materials Department - DEMAT, Federal University of Rio Grande do Sul - UFRGS, \\ Av. Osvaldo Aranha, 99/705, CEP 90035-190, Porto Alegre, RS, Brazil
}

Received: November 19, 2012; Revised: July 9, 2013

\begin{abstract}
The use of a waste from mineral processing, a spodumene-bearing rock, was investigated as a flux for bone china composition, partially replacing feldspar. The effect of lithium oxide in bone china body was favorable for reducing firing temperature. The presence of $\mathrm{Li}_{2} \mathrm{O}$ reacting with other oxides and silicates formed a liquid phase of lower viscosity, which was favorable for densification through viscous flow sintering, and to a higher mechanical strength. It was obtained a large plateau for firing, without deformation on firing (pyroplastic deformation) of parts; which is not an easy task to be achieved in bone china processing. Rheological and casting properties were also investigated. Microstructures of the fired bodies were discussed. They correlated well with the final properties of the parts.
\end{abstract}

Keywords: ceramics, porcelain, rheology, microstructure, recycling

\section{Introduction}

The use of waste in place of traditional materials from non-renewable sources has increased recently due to the growing interest in environmental preservation. There are a lot of examples in literature, such as the recycling of iron foundry sand, waste glass, waste from mineral processing, and so on ${ }^{1-4}$. By recycling one can reduce the environmental impact of traditional materials exploration, the environmental damages caused by incorrect administration of the tailings, and the risk of environmental accidents whenever residues are stored improperly. In addition, it is possible to reduce the monetary costs of the product manufacturing.

Bone china is produced with $50 \%$ of a recycled material such as calcined cattle bones. As a result of this trend of environmental conservation and utilization of recycling materials, bone china becomes one of the most attractive materials to be produced.

Bone china reaches higher prices comparing to others porcelains, due to its high technical and aesthetical quality. The properties are superior in terms of whiteness, brightness, translucency, and mechanical strength. It interesting to note that bone china production is still restricted to a few countries, such as Great Britain, Sweden, Japan, and the $\mathrm{USA}^{5}$.

In the present work, spodumene-bearing rock, a waste from mineral processing was used partially replacing feldspar, the traditional flux used in bone china formulation. Therefore, it was investigated the production of bone china with $60 \%$ of recycled materials. Recently, in a work performed by one of the authors, spodumene-bearing rock was successfully used as a flux for triaxial ceramic bodies ${ }^{6}$.

Several works has been published using raw materials containing spodumene in ceramic formulations. Tulyaganov et al. ${ }^{7}$ showed a reduction of $100-120{ }^{\circ} \mathrm{C}$ in the

*e-mail: saulorb@ufrgs.br sintering temperature of porcelains and concluded that the levels of $\mathrm{Li}_{2} \mathrm{O}$ should not exceed $1.5 \%$ to avoid bloating and the correspond decreasing of parts densification. Oberzan et al. ${ }^{4}$ tested the use of spodumene in alumina porcelain production, with a gain of densification, mechanical strength and decreasing the firing temperature.

The use of spodumene has not been tested before in bone china body. Usually, strong fluxes are difficult to use for bone china production because of the short firing range of this porcelain, limited by low thermal stability of parts ${ }^{8}$. The formation of a glass phase determines the firing temperature of the parts. The control of this phase is the key to reduce the cost associated with fuel consumption. Then, strong fluxes are used whenever it is possible in industrial production. However, the use of a strong flux, such as spodumene in bone china, has to overcome problems in firing, i.e., bloating and/or warping. Another point of interest in the present study was the development of a slip with spodumene, analyzing its rheology, and the properties of cast pieces.

\section{Experimental}

Two bodies were formulated according to the following raw materials proportions (in weight percentage):

i) Traditional bone china: $50 \%$ calcined bone, $25 \%$ kaolin and $25 \%$ feldspar;

ii) New body: $50 \%$ calcined bone, $25 \%$ kaolin, $15 \%$ feldspar and $10 \%$ spodumene.

The flux called "spodumene" is a tailing from the beneficiation of a rock for the extraction of tantalum. This waste rock contains the mineral spodumene $\left(\mathrm{LiAlSi}_{2} \mathrm{O}_{6}\right)$, and also quartz and albite. It was provided by Colorminas Company, being a by-product of mining pegmatites from Minas Gerais, Brazil. A detailed study of the properties of this rock, including the analysis of the reactivity with others raw materials was published in another paper ${ }^{6}$. 
Table 1 shows the chemical composition of raw materials, carried out by X-ray fluorescence (XRF model Shimadzu-1800), and crystalline phases determined by $\mathrm{X}$-ray diffraction (Philips model X'Pert MPD). Figure 1 shows the XRD pattern of spodumene-bearing rock. The main phases detected by X-ray diffraction were spodumene, albite, and quartz. An aluminum-silicate as a secondary phase was also detected (Figure 1).

Table 2 shows particle size distribution by laser diffraction (Model Cilas 1180). This analysis was performed after wet grinding in alumina media of the raw materials to sieve at 325 mesh (opening of $45 \mu \mathrm{m}$ ).

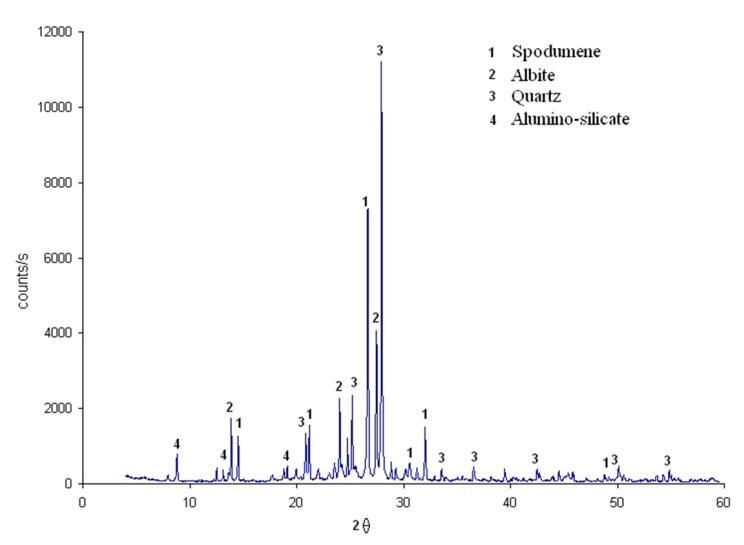

Figure 1. XRD pattern of spodumene-bearing rock.
The bone powder used here is from a company that produces handmade items, and is a waste from cutting and polishing of bovine bones, previously cleaned with caustic soda $(\mathrm{NaOH})$. In laboratory the bone powder was calcined at $1000{ }^{\circ} \mathrm{C}$, and milled until $90 \%$ of the particles were smaller than $14 \mu \mathrm{m}$, as recommended in the literature ${ }^{9,10}$.

The body formulations of the raw materials were mixed in the wet mill, dispersed with sodium silicate (solution in water) and passed through a sieve of 325 mesh. Next, the body was dried $\left(110^{\circ} \mathrm{C}\right)$ in an oven, moistened with water ( $8 \mathrm{wt} \%)$ and granulated by sieving mesh $20(0.84 \mathrm{~mm})$. The ceramic bodies were formed in hydraulic press, comminuted by a mortar, dried, mixed by hand and again moist ( $8 \mathrm{wt} \%)$, granulated (sieve $20 \mathrm{mesh}$ ) and pressed (at $\sim 30 \mathrm{MPa}$ ) to $8 \times 20 \times 60 \mathrm{~mm}^{3}$ dimensions. The pieces were naturally dried for 48 hours and in an oven at $110{ }^{\circ} \mathrm{C}$ for at least 24 hours. The density (in kerosene) of the dry parts was $\sim 1.90 \mathrm{~g} / \mathrm{cm}^{3}$. Tests were performed at least with 8 specimens of each test body formulation. The firing temperatures investigated ranged from 1180 to $1280{ }^{\circ} \mathrm{C}$ in an electric muffle furnace. The bodies of the four proposed formulations were fired simultaneously for each test temperature. The heating rate was $150{ }^{\circ} \mathrm{C} / \mathrm{h}$, and the dwell was 30 minutes at the maximum temperature.

The bodies were characterized for water absorption, linear shrinkage (per caliper), geometrical density (in an analytical balance and caliper), and four points flexural strength tests ${ }^{11,12}$. Deformation on firing test (also known as pyroplastic deformation or sag test) was performed with

Table 1. Chemical composition and phase analysis of raw materials.

\begin{tabular}{|c|c|c|c|c|}
\hline wt $\%$ & Kaolin & calcined bone ash & Potassic Feldspar & Spodumene \\
\hline $\mathrm{SiO}_{2}$ & 46.96 & 0.65 & 66.2 & 78.32 \\
\hline $\mathrm{Al}_{2} \mathrm{O}_{3}$ & 38.05 & 0.8 & 16.54 & 13.66 \\
\hline $\mathrm{Fe}_{2} \mathrm{O}_{3}$ & 0.46 & 0.12 & 0.15 & 0.24 \\
\hline $\mathrm{MgO}$ & - & 1.1 & - & - \\
\hline $\mathrm{CaO}$ & 0.02 & 52.2 & 0.36 & 0.44 \\
\hline $\mathrm{Na}_{2} \mathrm{O}$ & 0.03 & 2.1 & 0.89 & 1.16 \\
\hline $\mathrm{K}_{2} \mathrm{O}$ & 1.14 & 0.07 & 14.66 & 2.41 \\
\hline $\mathrm{TiO}_{2}$ & 0.03 & - & 0.03 & - \\
\hline $\mathrm{P}_{2} \mathrm{O}_{5}$ & 0.11 & 40.5 & 0.15 & 0.11 \\
\hline $\mathrm{Li}_{2} \mathrm{O}$ & - & - & - & $2.5^{*}$ \\
\hline Others & 0.03 & 0.2 & 0.64 & 0.94 \\
\hline LOI & 13.2 & 2.3 & 0.38 & 0.20 \\
\hline Major phases & $\begin{array}{c}\text { Kaolinite } \\
\text { Quartz } \\
\text { Moscovite }\end{array}$ & Hydroxy-apatite & $\begin{array}{c}\text { Quartz } \\
\text { Microcline } \\
\text { Albite }\end{array}$ & $\begin{array}{c}\text { Spodumene } \\
\text { Quartz } \\
\text { Albite }\end{array}$ \\
\hline
\end{tabular}

*analysis by atomic absorption.

Table 2. Raw materials particle size distribution. After wet milling.

\begin{tabular}{|c|c|c|c|}
\hline \multicolumn{4}{|c|}{ Raw material particle size distribution $(\mu \mathrm{m})$} \\
\hline Sample & $10 \%<(\mu \mathrm{m})$ & $90 \%<(\mu \mathrm{m})$ & Mean particle size $(\mu \mathrm{m})$ \\
\hline Calcined bone & 0.52 & 11.21 & 4.16 \\
\hline Kaolin & 2.35 & 14.26 & 7.89 \\
\hline Feldspar & 2.03 & 41.49 & 22.5 \\
\hline Spodumene & 1.28 & 37.68 & 15.11 \\
\hline
\end{tabular}


1 piece for each test condition, as described in Segadães ${ }^{13}$. The microstructure was observed in a scanning electron microscope (SEM - Jeol JSM-5800) with microanalysis by energy dispersive spectrometer (EDX - Noran). Samples were prepared for SEM by polishing (with SiC abrasive paper in decreasing particle size, ending with a suspension of alumina in wool), sometimes followed by acid etching (HF 20\%, at different times) to remove glass phase.

A casting slip was formulated with spodumene and then the density was adjusted to the proper value with addition of water, to make it comparable to the traditional formulation. The slip was prepared with $70 \%$ of solid and $30 \%$ of deionized water with addition of $0.15 \%$ deflocculant agent (ammonium polyacrylate). $1 \%$ of ball clay was added to the batch. Particle size distribution and surface area of the fluxes, and the slip densities for this study are in Table 3.

The characterization of the slip viscosity was made in a digital viscometer (model LVDV-II with small volume device, spindle SC4-18, Brookfield, Stoughton, MA). The deflocculant agent (ammonium polyacrylate) was added until the minimum viscosity was reached.

\section{Results and Discussion}

\subsection{Evaluation of firing behavior, mechanical strength, deformation on firing, and microstructure}

The properties of spodumene and feldspar bodies after firing are shown in Table 4. Figure 2 shows the large plateau for firing reached with spodumene body.

Feldspar body reached the desired vitrification at $1260{ }^{\circ} \mathrm{C}$ (Table 4). Ceramic pieces must have water absorption lower than $0.5 \%$ to be classified as porcelains. In the industrial firing process it is necessary large firing ranges for a body, which are formed by values of water absorption below $0.5 \%$. Lower temperatures for firing mean significant savings in fuel consumption.

The behavior of feldspar body on firing can be explained by the fact that it was used a potassium feldspar, which consists mainly of microcline $\left(\mathrm{KAlSi}_{3} \mathrm{O}_{8}\right)$. Alkali feldspars which have higher levels of albite $\left(\mathrm{NaAlSi}_{3} \mathrm{O}_{8}\right)$ showed vitrification between $1220^{\circ} \mathrm{C}-1240{ }^{\circ} \mathrm{C}$, in another studies ${ }^{5,8}$. By using conventional flux as alkali feldspar (richer in sodium than the feldspar used in this work) and/or nepheline syenite, it was showed similar firing ranges and in some cases, lower ones ${ }^{5,14,15}$. It must be noted that these are short intervals for firing, compared with other porcelains, such as hard porcelain ${ }^{14}$. The difficulty to obtain large firing ranges for bone china can be explained by the low amount of quartz in its formulation. This phase, in hard porcelain, undergoes gradual dissolution during firing, increasing the amount of silica in the glass phase, which ensures higher viscosity and, consequently, higher dimensional stability of the pieces at elevated firing temperatures ${ }^{16}$. Quartz particles showed low dissolution in bone china ${ }^{14}$.

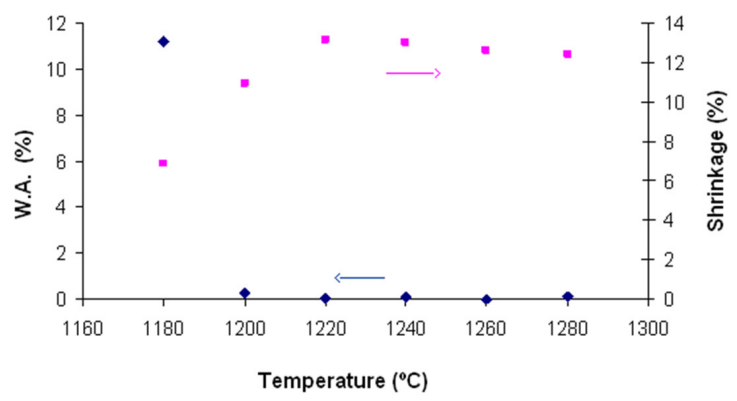

Figure 2. Linear shrinkage and water absorption (W.A.) as a function of firing temperature. Spodumene body.

Table 3. Raw materials particle size distribution, surface area and slip density used in slip casting analysis.

\begin{tabular}{cccccc}
\hline $\begin{array}{c}\text { Raw material particle } \\
\text { size distribution }(\boldsymbol{\mu m})\end{array}$ & $\mathbf{1 0 \%}<(\boldsymbol{\mu m})$ & $\mathbf{9 0 \%}<(\boldsymbol{\mu m})$ & $\begin{array}{c}\text { Mean particle size } \\
(\boldsymbol{\mu m})\end{array}$ & $\begin{array}{c}\text { Surface area } \\
\left(\mathbf{m}^{2} / \mathbf{g}\right)\end{array}$ & $\begin{array}{c}\text { Slip density } \\
\left(\mathbf{g} / \mathbf{c m}^{\mathbf{3}}\right)\end{array}$ \\
\hline Feldspar & 1.88 & 56.39 & 24.57 & 9.98 & 1.796 \\
Spodumene & 0.88 & 12.96 & 5.85 & 5.05 & 1.804 \\
\hline
\end{tabular}

Table 4. Technical characterization of fired bodies.

\begin{tabular}{lcccc}
\hline Body / Temperature $\left(\mathbf{C}^{\circ}\right)$ & Water Absorption $(\boldsymbol{\%})$ & Shrinkage $\mathbf{( \% )}$ & Apparent density $\left(\mathbf{g} / \mathbf{c m}^{3}\right)$ & $\sigma_{\mathbf{f}}(\mathbf{M P a})$ \\
\hline Spodumene & & & & \\
1180 & 11.22 & 6.88 & 1.97 & $36.1 \pm 3.8$ \\
1200 & 0.26 & 10.94 & 2.29 & $57.4 \pm 6.5$ \\
1220 & 0.04 & 13.11 & 2.38 & $77.0 \pm 9.3$ \\
1240 & 0.10 & 12.99 & 2.39 & $72.0 \pm 9.4$ \\
1260 & 0.00 & 12.62 & 2.37 & $75.5 \pm 5.5$ \\
1280 & 0.09 & 12.37 & 2.25 & $60.7 \pm 6.8$ \\
Feldspar & & & & \\
1240 & 1.22 & 8.80 & 2.17 & $41.1 \pm 4.3$ \\
1260 & 0.06 & 9.65 & 2.22 & $54.0 \pm 4.1$ \\
1280 & 0.05 & 9.59 & 2.16 & $48.1 \pm 4.7$ \\
\hline
\end{tabular}


As cited before, Figure 2 shows the firing range for spodumene body. This flux allowed a significant reduction of firing temperature, about $60{ }^{\circ} \mathrm{C}$ compared to feldspar body (Table 4). Therefore, the use of spodumene, partially replacing feldspar, reached not only a reduction of firing temperature, but also a wide range for firing. This is a very important achievement for bone china production.

Spodumene promoted the formation of glass phase at lower temperature, and also reduced viscosity at the same time, as expected, due to the presence of alkali oxides in silica glasses. This change the properties of glass phase in order to accelerate the densification by viscous flow ${ }^{17}$. According to the literature, the small lithium ion has the highest diffusion coefficient in liquid phases such as silicates, ${ }^{18}$ what explains the easier vitrification of the spodumene formulation.

Spodumene body shows low shrinkage and high porosity at $1180{ }^{\circ} \mathrm{C}$. This is expressed in terms of water absorption (Figure 2, Table 4). However, at $1200^{\circ} \mathrm{C}$ it presented fully vitrification. As it is known, the spodumene mineral melts at $\sim 1420{ }^{\circ} \mathrm{C}$, but there are two eutectics at $\sim 1020{ }^{\circ} \mathrm{C}$ in the diagram $\mathrm{Li}_{2} \mathrm{O}-\mathrm{SiO}_{2}$. In the $\mathrm{Li}_{2} \mathrm{O}-\mathrm{SiO}_{2}-\mathrm{Al} 2 \mathrm{O} 3$ ternary diagram, the eutectic is below $1000{ }^{\circ} \mathrm{C}$ in approximately $15 \% \mathrm{Li}_{2} \mathrm{O}-79 \% \mathrm{SiO}_{2}-8 \% \mathrm{Al}_{2} \mathrm{O}_{3}{ }^{[19]}$.

Considering a global analysis, it can be observed that the composition of spodumene belongs to the system $\mathrm{SiO}_{2}$ $\mathrm{Li}_{2} \mathrm{O}-\mathrm{Al}_{2} \mathrm{O}_{3}$ and is located in the triangle compatibility of $\mathrm{Li}_{2} \mathrm{O} .2 \mathrm{SiO}_{2}-\mathrm{SiO}_{2}-\mathrm{Li}_{2} \mathrm{O} \cdot \mathrm{Al}_{2} \mathrm{O}_{3} \cdot 4 \mathrm{SiO}_{2}$, whose invariant point (eutectic) is between 950 and $1000^{\circ} \mathrm{C}$. Thus, spodumene acts as an auxiliary flux, therefore, it tends to form the liquid phase (at the mentioned temperatures) before reacting with the other constituents of the mixture, and the densification of the body will be promoted by the presence of this liquid phase.

For comparison, Table 4 shows the two formulations studied as oxides. The level of $\mathrm{P}_{2} \mathrm{O}_{5}$, which may be considered a flux according to previous studies, as proposed in Cooper $^{10}$ and Iqbal et al. ${ }^{8,15}$, is identical in the both formulations. It can also be considered identical the amount of tricalcium phosphate formed. The same can be said about the minor constituents $\mathrm{Fe}_{2} \mathrm{O}_{3}, \mathrm{MgO}, \mathrm{TiO}_{2}$ and others (see Table 5). This highlights the importance of the $\mathrm{Li}_{2} \mathrm{O}$ in sintering mechanism.

The deformation on firing test (sag test) showed that no deformation occurred in the parts for the temperature range studied. Therefore, the surface tension of glass phase was high enough to avoid distortion of the pieces, for both bodies tested. Spodumene could accelerate the sintering reactions, but without significantly changing of the surface tension of the glass phase. This hypothesis is based on the fact that spodumene has the particularity to react as a strong flux, but at the same time increases the surface tension of the glass phase, as reported in the literature ${ }^{20}$.

In studies performed by the authors recently, other fluxes were investigated in bone china formulation. A reduction in sintering temperature was also obtained using wollastonite and waste glass as fluxing agents, but only wollastonite could achieve a large plateau for firing similar to spodumene ${ }^{21,22}$. A detailed comparative investigation of these fluxes is in preparation.

The presence of spodumene changes a little the thermal expansion, compared to feldspar body (Figure 3). The linear expansion coefficient calculated for the temperature range of $24^{\circ} \mathrm{C}-400{ }^{\circ} \mathrm{C}$ resulted in: $9.7 \times 10^{-6} \mathrm{~K}^{-1} ; 9.0 \times 10^{-6}$ $\mathrm{K}^{-1}$; for the feldspar and spodumene bodies, respectively. These values are close to the theoretical value $\left(\sim 8.4 \times 10^{-6}\right.$ $\mathrm{K}^{-1}$ ) calculated by the "rule of mixtures" of the constituent phases, considering $40 \% \beta$-tricalcium phosphate, $30 \%$ anorthite, and $30 \%$ glass phase ${ }^{15}$. The small difference between theoretical and measured values was expected due to the presence of quartz in some raw materials, and/ or variations in phase quantities. Diffraction analysis showed $\beta$-tricalcium phosphate, anorthite, and quartz in spodumene body after firing. Therefore, it can be deduced that all spodumene was decomposed, and incorporated into the glass phase.

It was observed that spodumene flux did not significantly change the thermal expansion of the parts produced, so it is not necessary to develop special glazes for this body.

Figure 4 shows the microstructure of feldspar and spodumene bodies. Feldspar body showed large pores and open porosity, while spodumene had glassy phase covering the entire surface. This explains the differences of technical properties between the two formulations (Table 4).

The difference between the mechanical strength of the bodies can be seen clearly in Figure 4, because there is a direct relationship of pore size and the mechanical strength. As cited in literature, the larger the critical pore (flaw) size, the lower is the mechanical strength ${ }^{23}$. Nevertheless, both formulations achieved sufficiently high mechanical strength for china utilization.

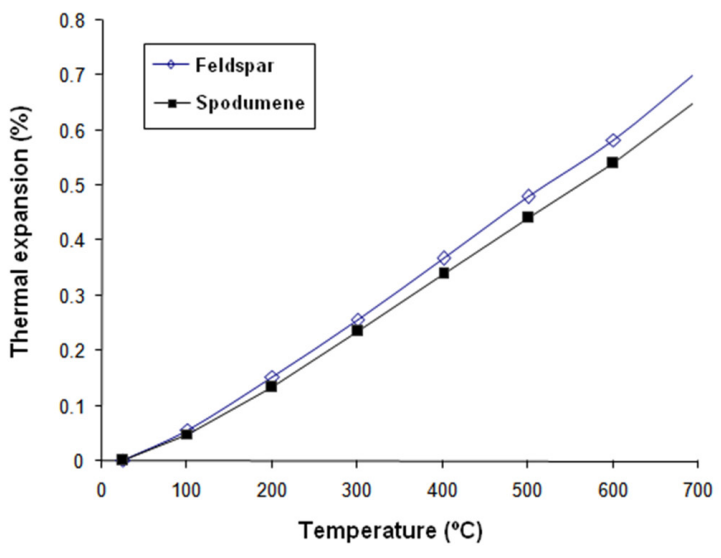

Figure 3. Linear thermal expansion.

Table 5. Feldspar (F) and Spodumene (S) bodies in oxide composition.

\begin{tabular}{ccccccccccccc}
\hline$(\%)$ & $\mathbf{S i O}_{2}$ & $\mathrm{Al}_{2} \mathbf{O}_{3}$ & $\mathrm{Fe}_{2} \mathbf{O}_{3}$ & $\mathbf{M g O}$ & $\mathbf{C a O}$ & $\mathbf{N a}_{2} \mathbf{O}$ & $\mathbf{K}_{2} \mathbf{O}$ & $\mathbf{L i}_{2} \mathbf{O}$ & $\mathbf{T i O}_{2}$ & $\mathbf{P}_{2} \mathbf{O}_{5}$ & Others & $\mathbf{P F}$ \\
\hline $\mathrm{F}$ & 28.62 & 14.05 & 0.21 & 0.55 & 26.20 & 1.28 & 3.99 & 0.00 & 0.02 & 20.31 & 0.27 & 4.55 \\
$\mathrm{~S}$ & 29.83 & 13.76 & 0.22 & 0.55 & 26.20 & 1.31 & 2.76 & 0.25 & 0.01 & 20.31 & 0.30 & 4.53 \\
\hline
\end{tabular}


In Figures 5 and 6 it can be seen, after acid attack to remove the glass phase, the major differences between the bodies in relation to pore size and crack pattern, notably higher for the feldspar body. A fractured microstructure is observed for both bodies. This occurs as a consequence of the stress generated due to the difference in thermal expansion between the matrix and the clusters of grains of $\beta$-tricalcium phosphate ${ }^{15}$. The differences in grain size, amount of crystalline phase and porosity also explains the difference in the properties of the bodies. They are all influenced by the presence of a strong flux such as spodumene, which determines the amount of glass phase generated, sintering temperature, as well as glass phase viscosity.

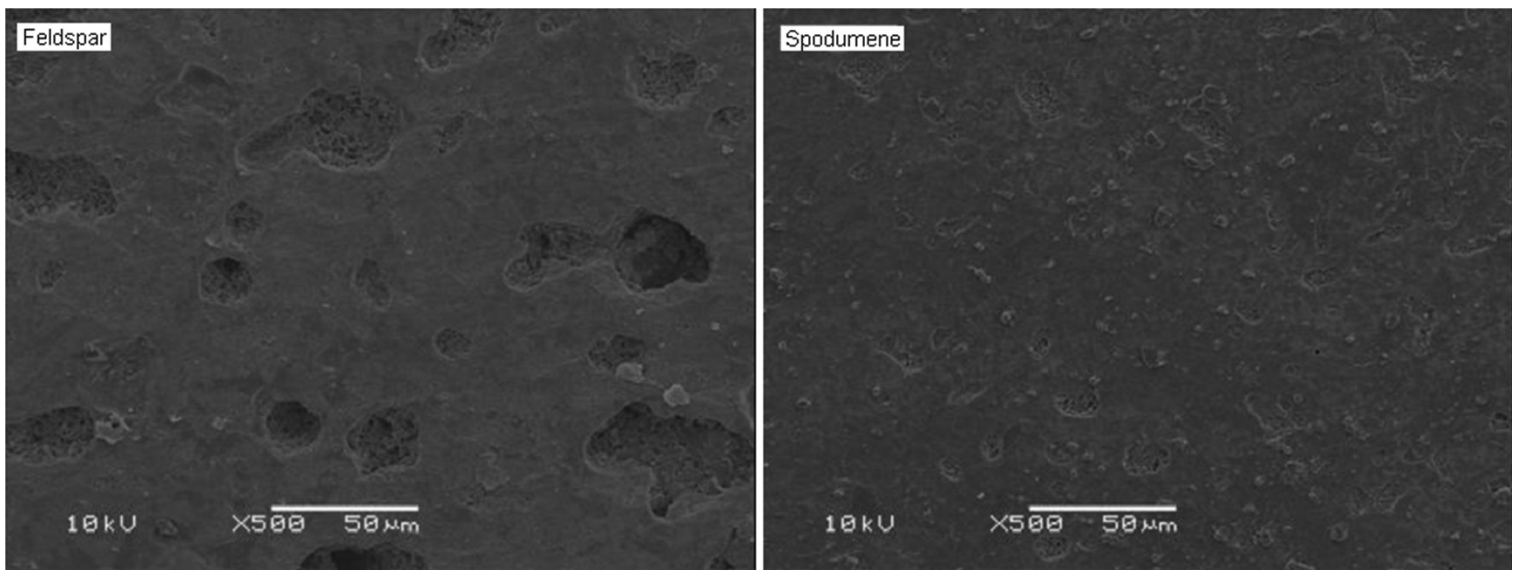

Figure 4. Images (SEM): no chemical etching Feldspar, and spodumene bodies fired at $1240{ }^{\circ} \mathrm{C}$.



Figure 5. Images (SEM): chemical etching (20\%HF, 20 s); Feldspar body fired at $1240{ }^{\circ} \mathrm{C}$.



Figure 6. Images (SEM): chemical etching (20\%HF, $20 \mathrm{~s})$; Spodumene body fired at $1240{ }^{\circ} \mathrm{C}$. 


\subsection{Slip casting characterization}

In Figure 7, the partial replacement of feldspar with spodumene showed little influence on the final apparent viscosity of the suspensions. The differences in initial viscosity and viscosities at low shear rates, between the slips, can be attributed to the differences in particle size (Table 3). The substitution of raw materials, even partially, modifies the particle size distribution, and this is one of the factors that affect directly the dispersion curve and the rheology of suspensions. Tallon et al. ${ }^{24}$ explain that a reduction in particle diameter increases the surface area, and as a consequence of that there is an increase in apparent viscosity of the suspensions. The data from these authors match the results of viscosity analysis (Figure 7). Spodumene has a lower average particle diameter (Table 3). Figure 7 also shows that the viscosity of the suspensions decreases

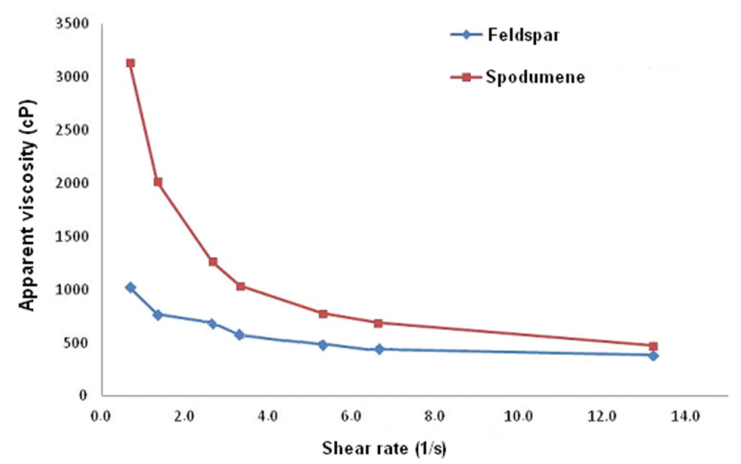

Figure 7. Shear stress in function of shear rate. $0.15 \%$ of dispersant was used for mixing.



Figure 8. Rheological behavior of spodumene. $0.15 \%$ and $0.2 \%$ of dispersant.

Table 6. Slip properties. Shear rate of $0.7 \mathrm{~s}^{-1}$.

\begin{tabular}{lcc}
\hline \multicolumn{1}{c}{ Bodies } & Feldspar & Spodumene \\
\hline Initial viscosity (cP) & 1024.0 & 3584.0 \\
Viscosity after deflocculation & 832.0 & 576.0 \\
at $0.2 \mathrm{wt} \%$ of dispersant $(\mathrm{cP})$ & & \\
Thickness of wall-forming in & 3.02 & 3.04 \\
3 min $(\mathrm{mm})$ & & \\
\hline
\end{tabular}

as shear rate increases, which is a typical behavior of a Bingham curve, a desired behavior for porcelain slips ${ }^{25,26}$.

Figure 8 illustrates rheological curves and their response of dispersant addition for the adjustment of spodumene slip. The addition of a higher amount of the dispersant did not change the trend of the curves: the increase of the shear rate reduces the viscosity of the slips. The characteristic Bingham behavior of rheology studies can be observed by both the decay of the viscosity, as for the increase in shear stress with respect to shear rate ${ }^{27}$. The data recorded in Brookfield viscometer showed the high effectiveness of the dispersant used.

It can be considered that viscosity values in Figure 8 are practically optimized for industrial casting, which uses a slip viscosity of $\sim 800 \mathrm{cP}$ and a wall thickness of $\sim 2 \mathrm{~mm}$ in $3 \mathrm{~min}$ of an assay. Therefore, these values are quite close to those obtained with the tested slips (Spodumene slip: $3.04 \mathrm{~mm}$ in $3 \mathrm{~min}, 576 \mathrm{cP}$ and; feldspar slip: $3.02 \mathrm{~mm}$ in $3 \mathrm{~min}, 832 \mathrm{cP}$ ). A high viscosity produces a rapid wall formation, as it would be expected for the slips with $0.15 \%$ dispersant. According to Hermann ${ }^{28}$ forming very thick walls in a short period of time may be a result of lack of dispersion and / or a high thixotropy. These factors lead to formation of defects in the parts processed by slip casting.

Figures 7 and 8 and Table 6 have shown that the partial replacement of the feldspar flux has not changed significantly the rheological behavior of the slips. The stabilization of the spodumene slip was achieved with a small consumption of dispersant, and practically the same of the feldspar slip. As the slips had already been prepared with $0.15 \%$, a total of $0.35 \mathrm{wt} \%$ dispersant was used. Both slips showed similar casting properties (Table 6). The density and viscosity of both slips are good for porcelain production.

\section{Conclusions}

A residue of mineral processing, a rock containing quartz, albite and spodumene, was successful in use as a flux of bone china. Partially replacing the K-feldspar attained a lower firing temperature, and a large firing range. The fired parts have not presented pyroplastic deformation. Reducing sintering temperature means important savings in fuel consumption.

The firing behavior of the spodumene formulation can be explained by the eutectic at $950-1000^{\circ} \mathrm{C}$, in the triangle compatibility $\mathrm{Li}_{2} \mathrm{O} .2 \mathrm{SiO}_{2}-\mathrm{SiO}_{2}, \mathrm{Li}_{2} \mathrm{O} \cdot \mathrm{Al}_{2} \mathrm{O}_{3} \cdot 4 \mathrm{SiO}_{2}$, located in the system $\mathrm{SiO}_{2}-\mathrm{Li}_{2} \mathrm{O}-\mathrm{Al}_{2} \mathrm{O}_{3}$. Spodumene promotes the formation of the liquid phase before reacting with the other constituents of the mixture, and the densification of the body was promoted by the presence of this liquid phase by viscous flow. The two formulations studied had similar amounts of flux oxides $\left(\mathrm{P}_{2} \mathrm{O}_{5}, \mathrm{Fe}_{2} \mathrm{O}_{3}, \mathrm{MgO}, \mathrm{TiO}_{2}\right.$ and others). This highlights the importance of the $\mathrm{Li}_{2} \mathrm{O}$ in a body composition.

The small lithium ion, provided by spodumene flux, in silicates glass has the particularity to reduce the temperature of firing, without decreasing the surface tension of the glass phase. This explains the large range for firing.

Microstructure analyses point out the causes of a higher mechanical strength of the spodumene body. This body showed higher densification, and consequently, smaller 
pore size (critical flaw size). Both formulations achieved sufficiently high mechanical strength for china utilization.

The partial replacement of the feldspar flux has not changed significantly the rheological behavior of the slips. Feldspar and spodumene slips bodies showed similar rheological properties, with stabilized suspensions, and

\section{References}

1. Tarvornpanich T, Souza GP and Lee WE. Microstructural Evolution on Firing Soda-Lime-Silica Glass Fluxed Whitewares. Journal of the American Ceramic Society. 2005; 88(5):1202-1208. http://dx.doi.org/10.1111/j.15512916.2005.00292.x

2. Braganca SR, Vicenzi J, Guerino K and Bergmann CP. Recycling of iron foundry sand and glass waste as raw material for production of whiteware. Waste Management \& Research. 2006; 24:60-66. PMid:16496871. http://dx.doi. org/10.1177/0734242X06061155

3. Bragança SR and Bergmann CP. Waste glass in porcelain. Materials Research. 2005; 8(1):39-44. http://dx.doi. org/10.1590/S1516-14392005000100008

4. Oberzan M, Holc J, Buhb M, Kuscer D, Lavrac I and Kosec M. High-alumina porcelain with the addition of a Li2Obearing fluxing agent. Journal of the European Ceramic Society. 2009; 29:2143-2152. http://dx.doi.org/10.1016/j. jeurceramsoc.2009.01.029

5. Portillo CG. Influence of the type of melting on the properties of bone porcelain. Boletín de la Sociedad Española de Cerámica y Vidrio. 1998; 38(5):397-402.

6. Bragança SR, Lengler HCM and Bergmann CP. Spodumenebearing rock as flux for triaxial ceramic bodies. Advances in Applied Ceramics. 2011; 110(5):293-300. http://dx.doi.org/1 $0.1179 / 1743676111 Y .0000000018$

7. Tulyaganov DU, Agathopoulos S, Fernandes HR and Ferreira JMF. Influence of lithium oxide as auxiliary flux on the properties of triaxial porcelain bodies. Journal of the European Ceramic Society. 2006; 26:1131-1139. http://dx.doi. org/10.1016/j.jeurceramsoc.2005.01.036

8. Iqbal Y, Messer PF and Lee WE. Non-equilibrium microstructure of bone china. British Ceramic Transactions. 2000; 99(3):110116. http://dx.doi.org/10.1179/096797800680811

9. Basnett D and Cartwrigtht PJ. Effect of bone properties on China casting. Transactions and Journal of the British Ceramic Society. 1989; 88(5):191-195.

10. Cooper JJ. Bone for bone China. British Ceramic Transactions. 1995; 94(4):165-168.

11. American Society for Testing and Materials - ASTM. C134-95: Standard Test Methods for Size, Dimensional Measurements and Bulk Density of Refractory Brick and Insulating Firebrick. Philadelphia: ASTM; 2010.

12. American Society for Testing and Materials - ASTM. C-133/97: Standard Test Methods for Cold Crushing Strength typical Bingham curves. The desired viscosity and also the stabilization of the spodumene slip were achieved with a small consumption of dispersant.

\section{Acknowledgements}

The authors acknowledge CNPq for scholarship support.

and Modulus of Rupture of Refractories. Philadelphia: ASTM; 2008

13. Segadães AM. Refratários (Refractories). Universidade de Aveiro; 1997. p. 40-41.

14. Bragança SR and Bergmann CP. A comparative study between bone China and hard porcelain. Industrial Ceramics. 2008; 28(3):189-194.

15. Iqbal Y, Messer PF and Lee WE. Microstructural evolution in bone china. British Ceramic Transactions. 2000; 99(5):193199. http://dx.doi.org/10.1179/096797800680938

16. Schüller KH. Porcelain. In: Ceramics Monographs - A Handbook of Ceramics. Verlag Schmidt GmbH Freiburg; 1979. p. 1-6.

17. Lee WE and Iqbal Y. Influence of mixing on mullite formation in porcelain. Journal of the European Ceramic Society. 2001; 21(14):2583-2586. http://dx.doi.org/10.1016/S0955$2219(01) 00274-6$

18. Navarro JMF. El Vidrio (Glass). Madrid: CSIC; 1991.

19. Eppler RA. Glass Formation and Recrystallization in the Lithium Metasilicate Region of the System $\mathrm{Li}_{2} \mathrm{O}-\mathrm{Al}_{2} \mathrm{O}_{3}-\mathrm{SiO}_{2}$. Journal of the American Ceramic Society. 1963; 46(2):100. http://dx.doi.org/10.1111/j.1151-2916.1963.tb11685.x

20. Sinton CW. Raw materials for glass and ceramics. New Jersey: John Wiley \& Sons; 2006. p. 182-196.

21. Carus LA, Souza F and Bragança SR. Use of Wollastonite as a Flux for Bone China Bodies. ISRN Ceramics. 2012: 1-7. http:// dx.doi.org/10.5402/2012/701821

22. Carus LA. and Bragança SR. Bone china formulated with waste glass. Advances in Applied Ceramics. 2013; 112(3):169-175. http://dx.doi.org/10.1179/1743676112Y.0000000065

23. Davidge RW. Mechanical behaviour of ceramics. Cambridge: Cambridge University Press; 1979.

24. Tallon C, Limacher M and Franks GV. Effect of particle size on the shaping of ceramics by slip casting. Journal of the European Ceramic Society. 2010; 30:2819-2826. http://dx.doi. org/10.1016/j.jeurceramsoc.2010.03.019

25. Reed JS. Principles of Ceramic Processing. 2nd ed. Oxford: John Wiley \& Sons; 1995.

26. Schilling $\mathrm{CH}$ and Aksay IA. Slip Casting. In: ASTM Engineered Materials Handbook Vol. 4: Ceramics and Glasses. Cleveland: ASTM International; 1991. p. 153-158.

27. Dinger DR. Rheology for ceramists. Clemson; 2002.

28. Herrmann R. Slip Casting in Practice. In: Ceramics Monographs - Handbook of Ceramics. Freiburg: Verlag Schmidt; 1989. p. 1-5. 